\title{
血友病診療における合成基質法
}

小川実加 ${ }^{1 *}$, 鈴木敦夫 ${ }^{2}$, 鈴木伸明 $^{3}$, 中山享之 ${ }^{1}$

\section{Chromogenic assay in hemopihilia treatment}

\author{
Mika OGAWA, Atsuo SUZUKI, Nobuaki SUZUKI, Takayuki NAKAYAMA
}

Key words: hemophilia, factor activity assay, chromogenic assay, one-stage assay, clinical laboratory

\section{1. はじめに}

血友病は凝固因子活性により重症度が分類され る。活性值は臨床的出血症状とよく相関し, 血液凝 固因子製剤の補充療法など治療へ反映されるため, その精確性は極めて重要である。血液凝固因子活性 の測定は，古くから主に凝固一段法により行われて おり，本邦では自動化が進んでいることからも広く 普及している，一方，欧州で主に用いられてきた合 成基質法は，自動分析装置に搭載可能な試薬が開発 されたことを皮切りに, 本邦でも2017 年に合成基質 法による第 VIII 因子（FVIII）活性測定，2018 年に 同じく合成基質法による第 IX 因子（FIX）測定が保 険収載された。ここでは血友病における凝固一段法 と合成基質法の特性や，合成基質法による凝固因子 活性測定の現状と今後の最適な臨床応用について述 ベたい.

\section{2. 凝固因子活性の測定法（図 1）}

世界的にみて最も普及している凝固一段法は，プ ロトロンビン時間（PT）あるいは活性化部分トロン ボプラスチン時間（APTT）の原理に基づく手法であ る. ある凝固因子欠乏血漿の凝固時間が，標準血漿

\footnotetext{
1 愛知医科大学病院中央臨床検査部

2 名古屋大学医学部附属病院医療技術部臨床検査部門

3 名古屋大学医学部附属病院輸血部

*責任者連絡先 :

愛知医科大学病院中央臨床検査部

T 480-1195 愛知県長久手市岩作雁又 1 番地 1

Tel: 0561-62-3311, Fax: 0561-63-1396

E-mail: ogawa.mika.948@aichi-med-u.ac.jp
}

あるいは被検血漿の添加により補正される程度を比 較することで被検血漿中におけるその凝固因子活性 を求める. 例えば, FVIII 活性測定では希釈した検体 血漿と FVIII 因子久乏血漿を混和し, APTT 試薬を添 加してインキュベーションを行なった後, カルシウ ムを加え凝固時間を測定する. 測定した凝固時間を, あらかじめ FVIII 活性が判明している標準血漿を用 いて作成した検量線と対応させることで検体血漿の FVIII 活性を求める. 通常, 自動分析装置による測定 では，単一の希釈倍率で実施する single-dilution analysis が主流であるが，WFHのガイドライン ${ }^{1)}$ で は3 種類の異なる希釈系列で測定を行い, 標準血漿 の希釈系列に対し parallel になるかを確認する手法 (multi-dilution analysis, parallel-line analysis) が推奨さ れている.この方法はループスアンチコアグラント （LA）や抗凝固片の影響を受けやすく, その存在を 検証することが可能である.

一方の合成基質法は，2段階の反応により構成さ れる。一段階目で被検血漿中の FVIII あるいは FIX 活性に依存した活性化第 X因子（FXa）が生成され, 二段階目で FXa に対する特異的な発色性合成基質と 反応させることにより，生成したFXaを定量する。 FVIII 活性測定を例に挙げると，一段階目で希釈した 被検血漿に FVIII 活性化のためのトロンビンと活性 化 FIX, FX, リン脂質およびカルシウムを加えイン キュベーション時間を長くとる. 十分な FXaを生成 させたところで二段階目として発色性合成基質を加 え, その発色を定量することで生成した FXaを測定 する。この FXa量は検体血漿中の FVIII 活性に依存 するため, 自動分析装置では吸光度や吸光度変化率 等を用いて, あらかじめ標準血漿を用いて作成した 

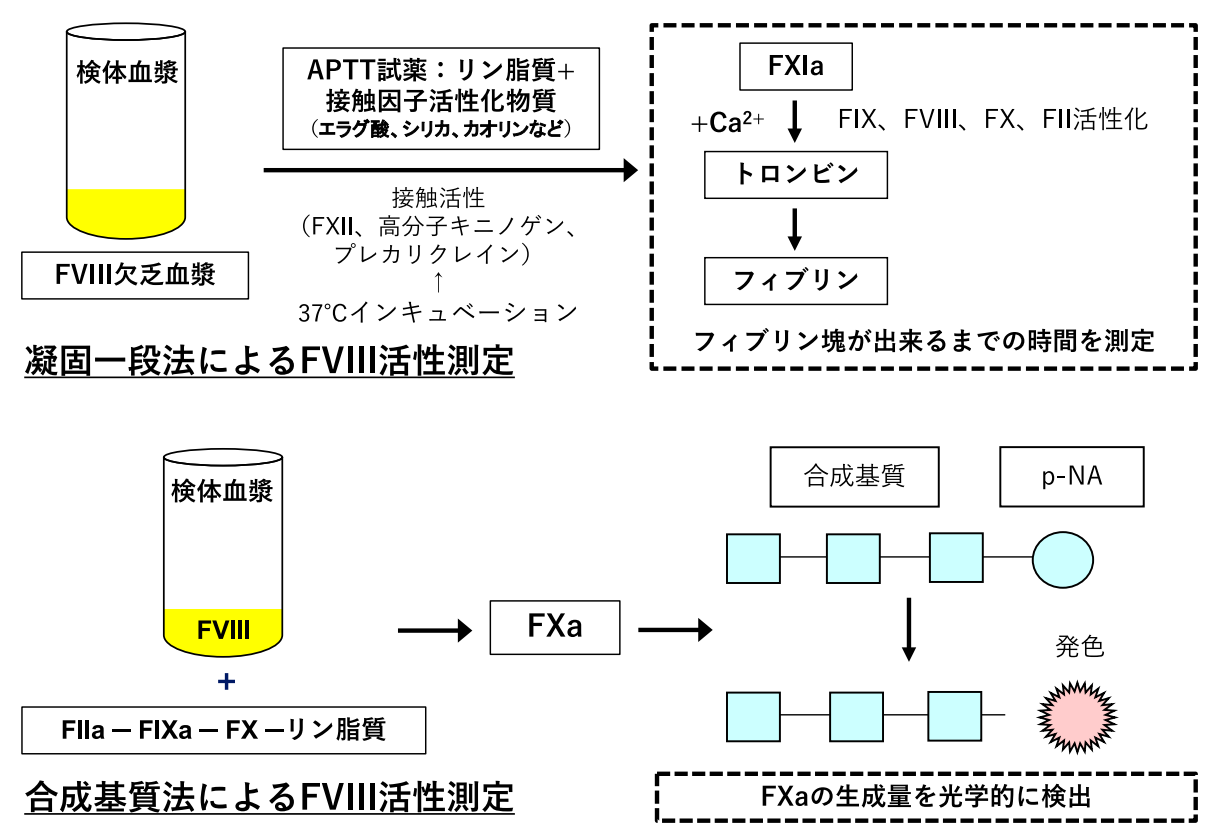

四 1 凝固一段法と合成基質法

凝固一段法：患者血漿に凝固因子欠乏血漿を基質として加え, APTT を測定.この際, APTT が患者血漿中の FVIII 活性依 存性に短縮することを利用し，その凝固因子活性を定量する方法.

合成基質法：内因系凝固過程において FXが FIXa，Ca，リン脂質抒よびFVIII の存在下でXaに変換される．Xaは合成ぺプ チド基質を特異的に分解し合成基質を遊離, その吸光度が FVIII の活性に依存することを利用する方法.

著者作成.

検量線から FVIII 活性を算出する。合成基質法は検 体血漿の希勫を十分にすることで, 時に凝固一段法 で問題となるLAの干渉やへパリンの影響を，受け にくいことが大きな利点の一つである.

\section{3. 凝固一段法の問題点}

凝固一段法は, 測定に用いる試薬（APTT 試薬 • 凝固因子久乏血漿を含む）や分析装置などが測定值 の差を生じる要素であることが知られている。また, 採血手技により偽高值となることや，LAの干涉を 受け偽低值となることがある ${ }^{2)}$ 。その他, APTTが 延長するへパリン製剤や直接トロンビン阻害薬（ダ ビガトラン）の使用ではその評価は困難である.

また, 軽症血友病 $\mathrm{A}$ 患者の $30 \%{ }^{3)}$, あるいは軽症 または中等症血友病 A 患者の 15～39\% ${ }^{4)}$ では, 凝固 一段法と合成基質法とでその活性值に乘離が生じる ことが知られている.これらの患者の臨床症状は合 成基質法の第 VIII 因子活性とよく相関するとされて
おり ${ }^{5)}$, 凝固一段法の測定のみでは正常な活性を示 し血友病と診断されない, あるいは実際の出血リス クよりも軽症とみなされる可能性がある。したがっ てWFH ガイドラインでは, 血友病 A の診断の際に は凝固一段法と合成基質法の両者を用いて FVIII 活 性を評価することが推奨されている ${ }^{1)}$.

さらに近年, 半減期延長型製剤 (extended half-life: EHL）や抗体製剤の開発がすすみ, 活性の精察はさ らに困難になっている．様々な分子修飾された EHL 製剤においては, APTT 試薬中の活性化剂の差が活 性值の差として顕現することがあり, 結果的に凝固 因子製剤によって測定結果に差異が生まれる ${ }^{6,7)}$. 抗 体製剤では，トロンビンによる第 VIII 因子活性化を 要することなく procoagulant活性を示すため, APTT に基づいた凝固一段法ではその活性值の評価はでき なくなる ${ }^{8)}$. 


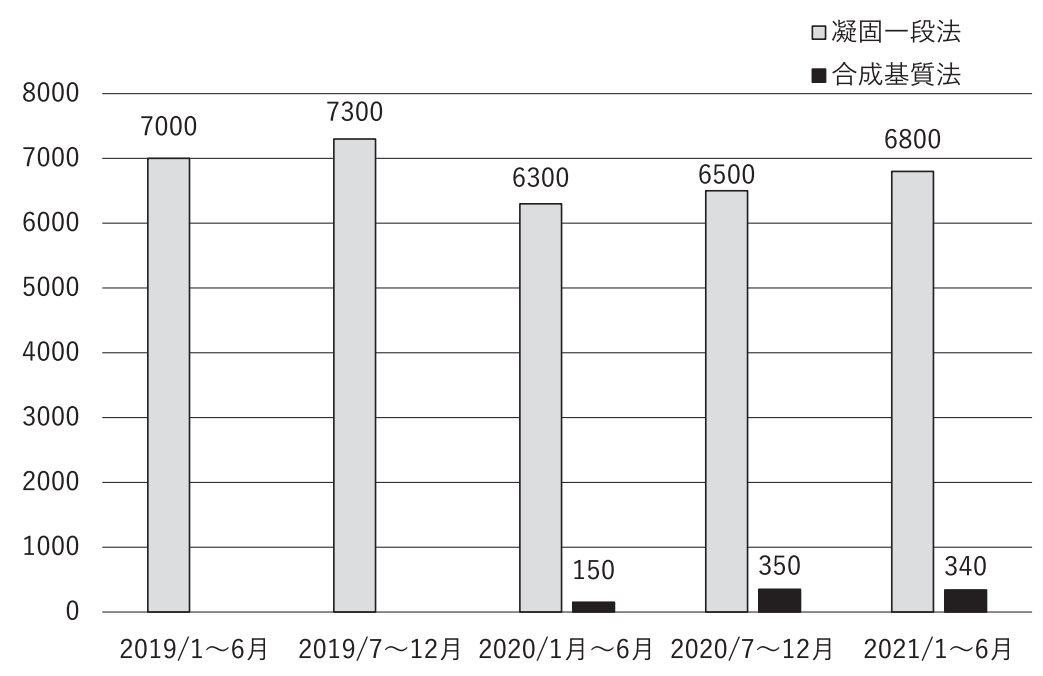

図 2 外部委託検査件数（FVIII 活性測定：凝固一段法と合成基質法） 著者作成.

\section{4. 本邦における合成基質法の現状}

凝固因子活性の測定は血友病拠点病院を中心に院 内の検査室で施行され，2種の合成基質試薬はいず れも毎年採用施設が増えており，2021年時点で全国 数十施設までFVIII 活性測定試薬の採用が進んでい る. 本邦での測定試薬の販売はそれぞれ一種類のみ であり，現状，測定装置も限定される。また，多く の施設では外部委託が一般的であり，合成基質法を 選択し依頼することが可能であるが，測定受託件数 は 2021 年時点で合成基質法は 5\%程度にとどまって いる(図2).

院内検査室での合成基質法による凝固因子活性測 定を実現するにあたって，当面の課題はそのコスト (採算性) である.もともとの検査件数が少ないこと から，凝固因子活性測定自体を院内で実施していな い施設が多い上に，合成基質法キットの試薬コスト が凝固一段法に比して高いことからさらにハードル が高くなっている。この試薬コストの問題について は海外でも一つの課題となっており, Kitchen らのシ ミュレーションデータでは, 1 バッチあたりの測定 件数によって凝固一段法と合成基質法の 1 テス卜費 用は大きく変わり，およそ 2 倍程度の差が生じると 示されている ${ }^{9)}$. 現在販売されている合成基質法キッ 卜は, 溶解後の試薬を凍結して保存し, 再融解して
使用することが可能であるため，できるだけ 1 バッ チあたりの検体数を確保し，コスト削減に努めるほ かないというのが現状である.

とはいえ, 実際の診療の際にはコスト以上に臨床 症状を反映していることが重要である. 血友病の診 断時や EHL 製剤のモニタリングなど，どのような機 会に合成基質法による測定をするべきか検討が必要 である。

\section{5. 二つの活性測定法で活性値が乘離する症例に は注意が必要}

現在の血友病治療における最も重要な目的は，定 期補充療法などの予防療法を最適化することにより, 関節内出血を極力抑え, 血友病性関節症を予防する ことである。しかし, 最近の研究では関節出血の減 少が血友病性関節症の発症を完全には予防しないこ とを示唆している ${ }^{10)}$. このような背景から, 関節内 出血の発症既往がない中等症以上の血友病でも, サ イレントに血友病性関節症が進行するのか，またこ れらの患者の FVIII 活性值を名古屋大学医学部附属 病院に通院する血友病 $\mathrm{A}$ 症例を対象に調査した ${ }^{11)}$. 対象症例は患者本人に関節内出血のエピソードがな く，さらに関節内出血の治療を受けた診療記録と製 剂投与記録が一度もない成人血友病 $\mathrm{A}$ 患者であり, 
表 1 臨床的に明らかな関節出血を認めない患者の PS に与える影響

\begin{tabular}{|c|c|c|c|c|c|}
\hline & \multicolumn{2}{|c|}{ PS negative $(\mathrm{N}=10)$} & \multicolumn{2}{|c|}{ PS positive $(\mathrm{N}=5)$} & \multirow{2}{*}{ P-value } \\
\hline & mean $\pm \mathrm{SD}$ & median $[\mathrm{IQR}]$ & mean $\pm \mathrm{SD}$ & median [IQR] & \\
\hline Age (years) & $42.2 \pm 16.1$ & $34[31.8,56.8]$ & $57.4 \pm 15.7$ & $67[40.5,69.5]$ & 0.342 \\
\hline FVIII: C(CSA) (\%) & $7.6 \pm 5.1$ & $9.3[1.7,11.2]$ & $4.5 \pm 1.2$ & $4.6[3.4,5.7]$ & $>0.999$ \\
\hline FVIII: C(OSA) (\%) & $8.6 \pm 4.0$ & $8.9[7.3,10.8]$ & $2.4 \pm 0.4$ & $2.2[2.1,2.9]$ & 0.118 \\
\hline FVIII: C ratio(CSA/OSA) & $0.9 \pm 0.4$ & $1.0[0.5,1.1]$ & $1.9 \pm 0.3$ & $1.8[1.6,2.2]$ & 0.020 \\
\hline FVIII:Ag (\%) & $19.3 \pm 20.5$ & $10.8[6.9,25.2]$ & $5.2 \pm 2.9$ & $4.9[2.4,8.2]$ & 0.120 \\
\hline PS & 0.0 & $0.0[0.0,0.0]$ & $6.8 \pm 5.1$ & $9.0[1.5,11.0]$ & - \\
\hline
\end{tabular}

CSA : 合成基質法, OSA : 凝固一段法, FVIII 活性：FVIII: C, FVIII 抗原：FVIII: Ag, PS：Pettersson score Mann-Whitney U test (Bonferroni correction)

Ogawa, M., et al., Thromb. Res. 188 (2020) 103-105.
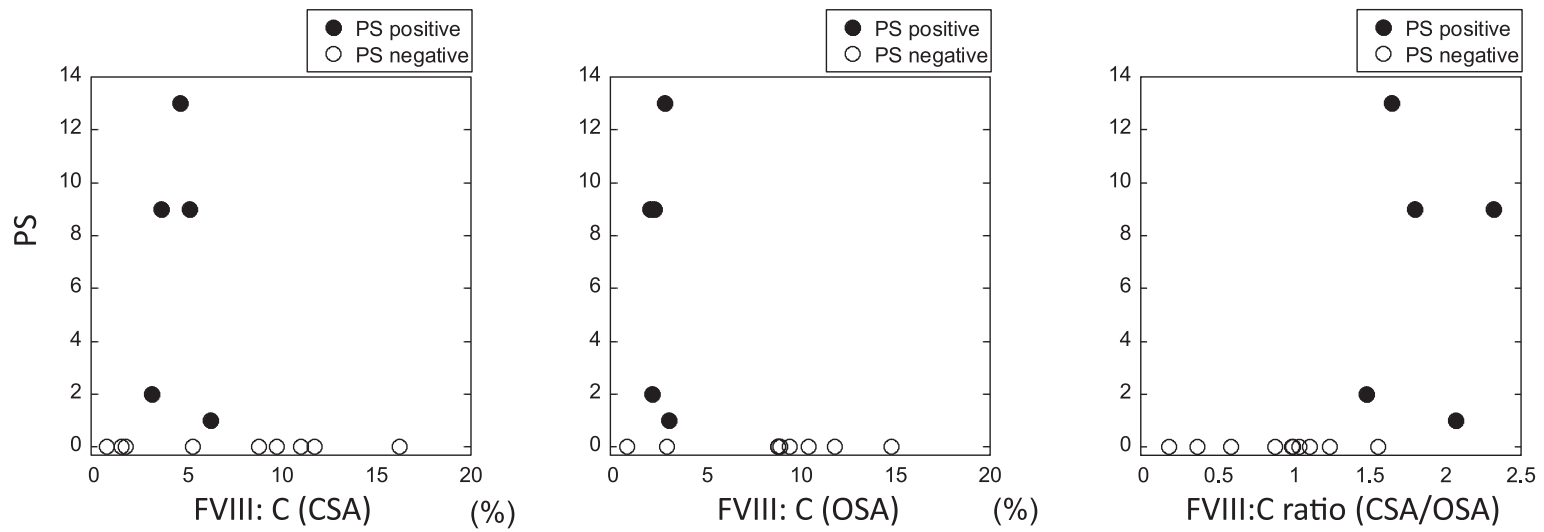

困 3 臨床的に明らかな関節出血を認めない患者における PS と FVIII 活性（FVIII: C) Ogawa, M., et al., Thromb. Res. 188 (2020) 103-105.

15 症例がリストアップされた。この 15 症例に対し, 両肘，膝，足関節のレントゲン評価を行い，血友病 性関節症の有無を確認した。この関節評価は pettersson score（PS）にて一人の整形外科医師が評 価を行った。結果はPS がゼロ（血友病性関節症が ない）の症例が 10 例, PSあり（血友病関節症あり） の症例が 5 例であった.PS あり症例は全体的に年齢 が高く, FVIII 活性值や FVIII 抗原量も低值という傾 向があったが, 統計上の有意差はなかった.しかし, 興味深いことに, PS ありの症例は合成基質法と凝固 一段法の活性值の值に大きな乘離があり，合成基質 法の值が凝固一段法の值の 2 倍程度高いという特徵 を有していた（表1，図3）。この研究結果から中等
症以上の関節内出血を発症しないような症例におい ても, 凝固一段法と比較して合成基質法で活性值が 高い症例では, サイレントに血友病性関節症が発症 し進行するリスクがあり注意が必要と考えられた。 このような結果となった理由として, 合成基質法で は活性測定の際に FVIII を活性化させるためのイン キュベート時間を十分に確保し, 最終的な FXaの生 成量を評価する検査法であるため, FVIIIが活性化し トロンビン生成が開始されるまでの時間的な評価は 含まれない。一方, 凝固一段法はフィブリン形成ま での時間を測定する APTT の測定原理を利用した検 查法であり，フィブリンクロット形成までにかかる 時間は評価されるが，生成したトロンビンを含めた 
量的な評価はされない。したがって, 凝固一段法よ り合成基質法で活性值が高くなる症例は, 最終的な FXa生成量はある程度保たれていても, 生成するま での時間を要するという特性が考えられる ${ }^{11)}$ 。微小 な関節内出血などを発症した際には, 痛みとして認 知される前に止血が得られるものの, 止血までにあ る程度の時間がかかるため, それを繰り返すことに より，長期的には血友病性関節症の発症につながる のではないかと考えられた。このように, 評価方法 の異なる二つの活性測定法は, 評価している対象も 異なるため, その結果の違いが血友病の臨床症状に も影響を与える可能性が示唆された。

\section{6. おわりに}

血友病診断時には凝固一段法と合成基質法の両 アッセイを評価する必要がある。これらの乘離を認 める患者では, より慎重な関節症の経過観察と補充 療法の強化が必要な可能性があり, 組み合わせるこ とで類推が可能である。 また, 血友病の新しい治療 オプションにより, 合成基質法による評価の重要性 は増しており, 今後その評価の妥当性の検討が必要 である。

著者の利益相反 (COI) の開示 :

鈴木伸明：臨床研究（治験）（サノフィ）

その他著者の利益相反 (COI) の開示 :

本論文発表内容に関連して開示すべき企業等との利 益相反なし

\section{文献}

1) Srivastava A, Santagostino E, Pierce G, et al.: WFH Guidelines for the management of hemophilia, 3rd edition. Haemophilia 26(Supple 6): 1-158, 2020.

2) Wayne L, Chris F, Hien K, et al.: Comparison of three methods for measuring factor VIII levels in plasma. Am J Clin Pathol 120: 34-39, 2003.

3) Bowyer AE, Van Veen JJ, Makris M, et al: Specific and global coagulation assays in the diagnosis of discrepant mild hemophilia A. Haematologica 98: 980-987, 2013.

4) Potgieter JJ, Damgaard M, Hillarp A: One-stage vs. chromogenic assays in haemophilia A. Eur J Haematol 94(Suppl. 77): 38-44, 2015.

5) Trossaert M, Lienhart A, Dargaud $Y$, et al.: Diagnosis and management challenges in patients with mild haemophilia A and discrepant FVIII measurements. Haemophilia 20: 550$558,2014$.

6) Adcock DM, Strandberg K, Marlar RA, et al.: Advantages, disdvantages and oprimization of one-stage and chromogenic factor activity assays in haemophilia A and B. Int J Lab Hem 40: 621-629, 2018.

7) Madoiwa S: Measurement of coagulation activity of patients with hemophilia using half-life extension coagulation factors. 血栓止血誌 29: 10-19, 2018.

8) Kitazawa $T$, Igawa $T$, Hattori $K$, et al.: A bispecific antibody to factors IXa and X restores factor VIII hemostatic activity in a hemophilia A model. Nat Med 18: 1570-1574, 2012.

9) Kitchen S, Blakemore J, Luddington RJ, et al.: A computerbased model to assess costs associated with the use of factor VIII and factor IX one-stage and chromogenic activity assays. J Thromb Haemost 14: 757-764, 2016.

10) Manco-Johnson MJ, Abshire TC, Hoots WK, et al.: Prophylaxis versus episodic treatment to prevent joint disease in boys with severe hemophilia. N Engl J Med 357: 535-544, 2007.

11) Ogawa M, Suzuki N, Matsushita $T$, et al.: Haemophilia A patients with higher FVIII:C from chromogenic substrate assay than from one-stage substrate assay are at higher risk of silent haemophilic arthropathy. Thromb Res 188: 103-105, 2020. 